\title{
Bulk Deposition and Source Apportionment of Atmospheric Heavy Metals and Metalloids in Agricultural Areas of Rural Beijing during 2016-2020
}

\author{
Yuepeng Pan ${ }^{1,2, * \mathbb{C}}$, Jin Liu ${ }^{1,2}$, Lan Zhang ${ }^{3}$, Jing Cao ${ }^{1,2}$, Jiabao Hu ${ }^{1}$, Shili Tian ${ }^{1,4}{ }^{\text {, Xingyu Li }}{ }^{5}$ and Wen $\mathrm{Xu}^{6}$ \\ 1 State Key Laboratory of Atmospheric Boundary Layer Physics and Atmospheric Chemistry, Institute of \\ Atmospheric Physics, Chinese Academy of Sciences, Beijing 100029, China; liujin@mail.iap.ac.cn (J.L.); \\ caojing315@mails.ucas.ac.cn (J.C.); hujiabao@nuist.edu.cn (J.H.); tianshili@mail.iap.ac.cn (S.T.) \\ 2 College of Earth and Planetary Sciences, University of Chinese Academy of Sciences, Beijing 100049, China \\ 3 The Analysis and Test Center, Capital Normal University, Beijing 100048, China; zhanglan3761@sina.com \\ 4 Beijing Center for Physical \& Chemical Analysis, Beijing 100089, China \\ 5 Key Laboratory of Cloud-Precipitation Physics and Severe Storms, Institute of Atmospheric Physics, Chinese \\ Academy of Sciences, Beijing 100029, China; lxy@mail.iap.ac.cn \\ 6 National Academy of Agriculture Green Development, Key Laboratory of Plant-Soil Interactions of MOE, \\ College of Resources and Environmental Sciences, China Agricultural University, Beijing 100193, China; \\ wenxu@cau.edu.cn \\ * Correspondence: panyuepeng@mail.iap.ac.cn
}

check for updates

Citation: Pan, Y.; Liu, J.; Zhang, L.; Cao, J.; Hu, J.; Tian, S.; Li, X.; Xu, W. Bulk Deposition and Source Apportionment of Atmospheric Heavy Metals and Metalloids in Agricultural Areas of Rural Beijing during 2016-2020. Atmosphere 2021, 12, 283. https://doi.org/10.3390/ atmos12020283

Academic Editor: Pascal Flament

Received: 30 December 2020

Accepted: 9 February 2021

Published: 22 February 2021

Publisher's Note: MDPI stays neutral with regard to jurisdictional claims in published maps and institutional affiliations.

Copyright: (c) 2021 by the authors. Licensee MDPI, Basel, Switzerland. This article is an open access article distributed under the terms and conditions of the Creative Commons Attribution (CC BY) license (https:/ / creativecommons.org/licenses/by/ $4.0 /)$.
Abstract: While atmospheric deposition plays a vital role in cleaning air pollutants, it also supplies toxic heavy metals and metalloids (MMs) to the receiving terrestrial and aquatic ecosystems and threatens human health through food chains. To characterize the input of atmospheric deposition to agricultural soils, bulk rain samples were collected on an event basis at a rural site in the North China Plain during 2016-2020. The results show that higher concentrations of MMs in bulk rain samples were associated with western and southern air masses passing polluted areas. In addition, the annual deposition flux of MMs tends to decline during the study period, coinciding with the inter-annual variations of particulate matter rather than the precipitation amounts. Of note, the deposition flux of MMs that exist entirely in fine particles declined significantly compared to those that exist in coarse particulate form, indicating that the clean air actions implemented in recent years were highly effective in reducing ambient MMs from anthropogenic emissions. The positive matrix factorization receptor model was also applied to the whole data set for bulk depositions and five sources were identified as agricultural (biomass burning and soil), dust, coal combustion, industrial and traffic emissions. These factors contributed $41 \%, 24 \%, 21 \%, 9 \%$ and $5 \%$ of the chemical components in bulk depositions, respectively. Future control strategies should tighten the emissions from combustion and soil/dust in the North China Plain to protect agriculture from atmospheric MMs depositions.

Keywords: atmospheric deposition; heavy metal; bulk rain sampling; wet deposition; dry deposition; bulk deposition; precipitation chemistry; agricultural soil pollution; North China Plain

\section{Introduction}

Heavy metals and metalloids (MMs) are a natural constituent of igneous rocks, soils and sediments [1]. In soils most MMs occur in relatively low concentrations, less than $100 \mathrm{mg} \mathrm{kg}^{-1}$ dry matter [2]. The MMs content in agricultural soils is, however, also dependent on other sources than mineralization of the indigenous minerals, e.g., irrigation water, sewage sludge, fertilizers and livestock manures [3]. Of note, external input from atmospheric deposition seems to be an important or even dominant pathway for most MMs in agricultural land areas [4].

Compared to the abundance of MMs in the earth's crust and in pristine soils, airborne particles and vapors emitted from energy production and industrial processes are enriched 
in MMs [5]. The substantial emissions of MMs from coal combustion and industrial products in China have resulted in much higher atmospheric concentration than the limit ceilings of WHO guidelines [6]. The life time of most MMs varies from days to weeks when emitted from elevated stacks associated with fine particles [7], causing widespread adverse effects and even trans-boundary environmental pollution disputes [8]. After the airborne MMs are deposited on plants and into soil or water, they can also cause substantial damages to the environment and human health due to their transfer and accumulation in food chains [4].

According to a report on China's Soil Pollution Survey by the Ministry of Environmental Protection and Ministry of Land and Resources in 2014, 19.4\% of the Chinese farmland soil was polluted. Of the contaminated soil samples, $82 \%$ contained toxic inorganic pollutants, the most common being heavy metals such as cadmium $(\mathrm{Cd})$, mercury $(\mathrm{Hg})$, arsenic (As), chromium $(\mathrm{Cr})$, and lead $(\mathrm{Pb})$, which can cause chronic health problems [9]. Since 2016, the Chinese government made great efforts to tackle soil pollution by implementing an Action Plan on Soil Pollution Prevention and Control. Earlier in 2013, a series of control measures was also launched to improve air quality in China. As a consequence, the concentrations of fine particles and sulfate aerosols were reduced significantly during 2013 to 2017 [10]. However, to what extent the clean air act in China can affect the atmospheric deposition is largely unknown due to the paucity of measurements.

Here we reported a continuous field observation of bulk depositions during 2016-2020 at a rural site in North China Plain, an area receiving high levels of atmospheric MMs deposition as documented ten years ago [4]. This study aims to (1) document the concentration levels of 11 selected MMs in bulk depositions, (2) examine the annual deposition flux of MMs due to the clean air actions, (3) apportion the source sectors and source regions of deposited MMs in rural agricultural areas. The findings presented here are important for policy-makers in designing mitigation strategies to reduce air pollutants in the target region, with significant implications for other developing regions experiencing severe air pollution.

\section{Experiments}

\subsection{Site Description and Sampling Method}

The sampling station located in a rural agricultural site $\left(40^{\circ} 29^{\prime} \mathrm{N}, 115^{\circ} 59^{\prime} \mathrm{E}, 500 \mathrm{~m}\right.$ a.s.l., Figure 1), about $70 \mathrm{~km}$ northwest (NW) of downtown Beijing. Bulk depositions were collected by an open-field plastic bucket in combination with a polyethylene funnel $(20 \mathrm{~cm}$ in diameter and $15 \mathrm{~cm}$ in height, Figure S1). In total, 150 samples were collected on an event basis during the period of November 2016 to November 2020. Of the total, 138 samples with volume larger than $5 \mathrm{~mL}$ were MMs determined with a logsheet shown in Table S1. Because the sampling device was always open to the atmosphere during the study period, the collected bulk samples included rain (wet deposition) and dry deposited particles from gravity falling processes after last rainfall. After measuring the rainfall volume, the bulk rain samples were stored in $50 \mathrm{~mL}$ PET vials at $-20^{\circ} \mathrm{C}$ until analysis.

After each sampling, the bulk deposition collector was cleaned with deionized water to ensure the quality of the subsequent sampling. Then, $500 \mathrm{~mL}$ deionized water was used to simulate rainfall, which was finally collected as blank samples. The blank samples collected in the field and the deionized water in the lab did not differ significantly for selected heavy metal(loid)s, indicating that the methodology used in the study was repeatable. Note that the bulk deposition sampler is passive in nature and subject to uncertainties in characterizing total deposition [11]. For example, our measurements are likely to underestimate dry deposition considering that the losing of resuspended particulates is possible due to strong winds [12]. 


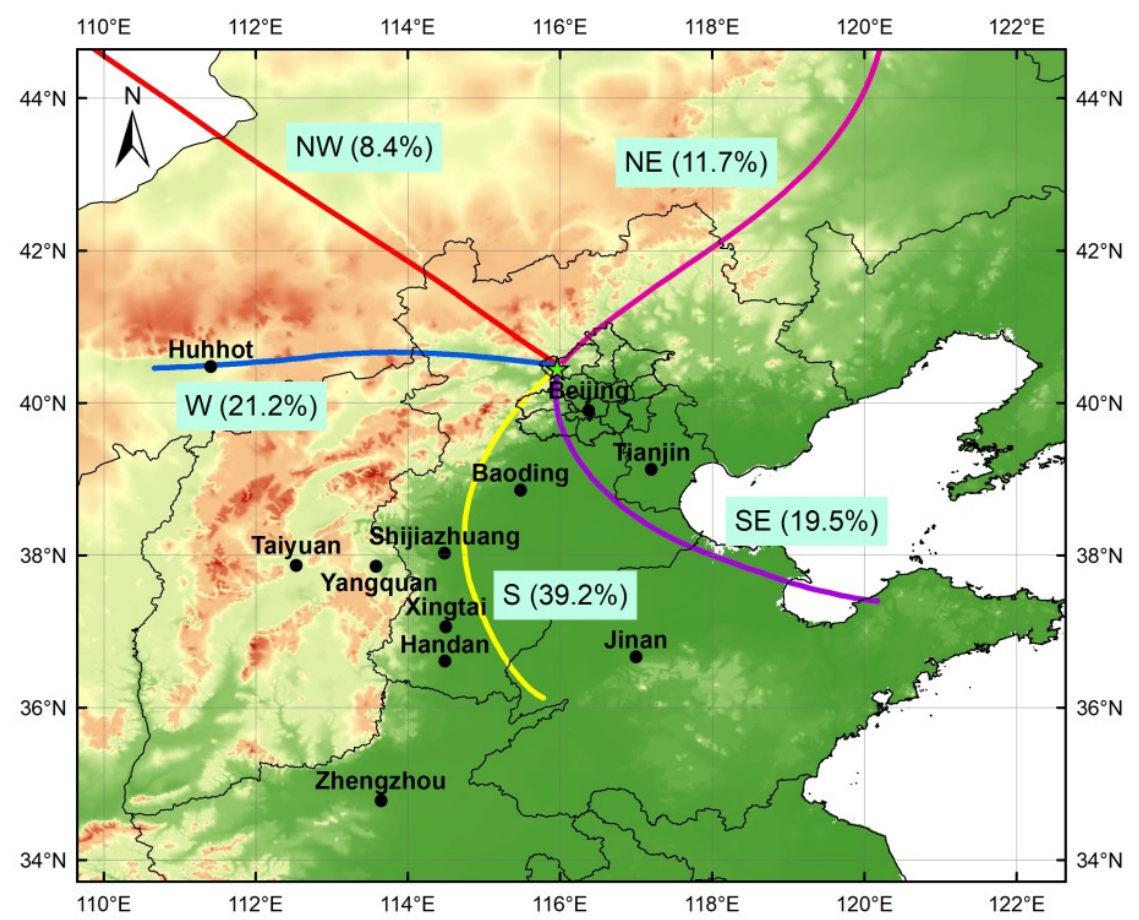

Figure 1. The sampling location (denoted as a star) in the North China Plain. Statistical cluster analysis of air mass backward trajectories showing pathways of air parcels prior to arrival at the sampling site. The percentage of trajectories occurring in each cluster is also shown along the pathways, including northwest (NW, 8.4\%), west (W, 21.2\%), south (S, 39.2\%), southeast (SE, 19.5\%) and northeast (NE, 11.7\%).

\subsection{Chemical Analysis}

When samples returned to the laboratory, an aliquot was filtered using $0.22-\mu \mathrm{m}$ filters and analyzed to determine the concentrations of $\mathrm{Na}^{+}, \mathrm{NH}_{4}^{+}, \mathrm{K}^{+}, \mathrm{Mg}^{2+}, \mathrm{Ca}^{2+}, \mathrm{F}^{-}, \mathrm{Cl}^{-}$, $\mathrm{NO}_{3}{ }^{-}$and $\mathrm{SO}_{4}{ }^{2-}$ with an ion chromatograph (Dionex, ICS-90, Sunnyvale, USA) [13]. Subsequently, dissolved organic carbon (DOC), inorganic carbon (IC), and total nitrogen (TN) concentrations were also analyzed using a Multi N/C 3000 Analyzer (Analytik Jena AG, Jena, Germany) [14]. An additional aliquot was acidified with $0.1 \mathrm{~mL} \mathrm{HNO}_{3}$ for trace elements (TEs) analysis. The concentrations of 25 TEs (Be, Na, Mg, Al, K, Ca, V, Cr, Mn, $\mathrm{Fe}, \mathrm{Co}, \mathrm{Ni}, \mathrm{Cu}, \mathrm{Zn}, \mathrm{As}, \mathrm{Se}, \mathrm{Mo}, \mathrm{Cd}, \mathrm{Sb}, \mathrm{Ba}, \mathrm{Tl}, \mathrm{Ag}, \mathrm{Pb}$, Th and $\mathrm{U}$ ) were determined using Agilent 7500ce inductively coupled plasma mass spectrometry (ICP-MS, Agilent, Tokyo, Japan) [6]. The analysis methods of the chemical species in this study have been detailed elsewhere [15].

\subsection{PMF Model}

Positive matrix factorization (PMF) is an effective source apportionment receptor model [16]. In this study, EPA-PMF 5.0 was applied for the bulk depositions, with above chemical species as input. In brief, the base model was run 20 times with a different number of factors to obtain the best possible solution. When a reasonable solution was found, the bootstrapping technique was used to obtain the most meaningful results. Of the 100 bootstrap runs, the factors were mainly mapped to a base factor in every run, which indicated a stable result. The uncertainty of the concentration data was also calculated according to Tian, et al. [17].

\subsection{PSCF Analysis}

We applied the potential source contribution function (PSCF) to identify the sources of MMs based on TrajStat [18]. The region of concern is divided into $i \times j$ equal grids $\left(0.25^{\circ} \times 0.25^{\circ}\right)$. The PSCF value in the $i j$-th grid is defined as $\mathrm{m}_{i j} / n_{i j}$, where $n_{i j}$ is designated 
as the number of endpoints that fall in the $i j$-th grid and $\mathrm{m}_{i j}$ denotes the numbers of "polluted" trajectory endpoints in the ij-th grid [19]. In this analysis, average concentrations were treated as the "polluted" threshold. To better reflect the uncertainty in grids with small $n_{i j}$ values [20], the weighting function $\mathrm{w}_{i j}$ was adopted as follows:

$$
\mathrm{W}\left(n_{i j}\right)=\left\{\begin{array}{c}
1.00 n_{i j}>80 \\
0.7020<n_{i j} \leq 80 \\
0.4210<n_{i j} \leq 20 \\
0.05 n_{i j} \leq 10
\end{array}\right.
$$

\section{Results and Discussion}

\subsection{Concentration Variations}

Figure 2 shows the seasonal variations of selected MMs in bulk deposition during 2017-2020. As shown, the seasonal pattern varied with MMs, and no consistent pattern was found. Considering the outliers in Figure 2, a simple average is probably not the best value to use. Alternatively, the median values provide a better summary statistic, avoiding bias toward large values. Compared with cold seasons, relatively low median values for most MMs were found in summer or autumn due to the solute dilution effect by monsoon precipitation [14]. For V, As, Mo and Tl, however, their median values were lowest in winter. In contrast, most MMs showed higher median concentrations in spring or winter due to the elevated emissions of dust and coal burning [4]. This is the case especially for $\mathrm{Pb}$, with median concentrations ten times higher than other seasons. After a close look at the concentrations of $\mathrm{Pb}$ during the study period, several extreme values were identified between November 2019 and February 2020, a typical house heating period in the target region. Thus, the intensive domestic coal use for house heating and less dilution of scavenged $\mathrm{Pb}$ due to lower precipitation together resulted in higher $\mathrm{Pb}$ concentrations in winter [4].

Since the concentrations of selected MMs were not always normally distributed, geometric and volume-weighted mean values were further calculated. During the observation period, the overall volume-weighted mean concentration of $\mathrm{Pb}\left(40.75 \mu \mathrm{g} \mathrm{L}^{-1}\right)$ was the highest (Table 1), followed by Zn (28.82), Cu (3.42), Ni (2.08), As (1.84), Cr (1.38), V (0.41), $\mathrm{Co}(0.17), \mathrm{Mo}(0.11), \mathrm{Cd}(0.11)$ and $\mathrm{Tl}(0.04)$. Although the particulate $\mathrm{Pb}$ concentrations was reduced from 24 to $2.3 \mu \mathrm{g} \mathrm{m}^{-3}$ between 1980s and 2000s at a background site in the target region [6], the bulk deposition of $\mathrm{Pb}$ presented here is still ten times higher than that observed from Norwegian background stations during 1995-2005 (lower than $3 \mu \mathrm{g} \mathrm{L}^{-1}$ ) [21]. The potential source regions of $\mathrm{Pb}$ according to PSCF analysis during this study period referred to the southwest (SW) transport pathway in the North China Plain (Figure S6), which is along the Mt. Taihang. Besides Beijing, Baoding and Handan, the PSCF analysis also suggested hotspot sources across the boundaries of Hebei, Shandong, and Henan provinces in the North China Plain, one region experiencing severe particle pollution [6].

The observation data were also subjected to back trajectory cluster analysis to identify the meteorological influences. The air masses reaching the observation site have five main pathways (Figure 1), including NW (8.4\%), west (W, 21.2\%), south (S, 39.2\%), southeast (SE, $19.5 \%$ ) and northeast (NE, 11.7\%). In general, relatively high MMs concentration in bulk deposition was associated with southern and western trajectories (Table 1). Specifically, higher concentrations of $\mathrm{V}, \mathrm{Cr}, \mathrm{Ni}$ and As coincided with air mass from the southern directions, while $\mathrm{Co}, \mathrm{Cu}, \mathrm{Zn}$ and $\mathrm{Pb}$ primarily originated from the western air masses. Notably, the concentrations of Mo and Cd were higher in the northeastern direction, followed by southern pathways. The findings suggested that the major sources of bulk deposition of MMs at the site were from the western and southern areas, with detailed spatial information shown in Figures S2-S6. 

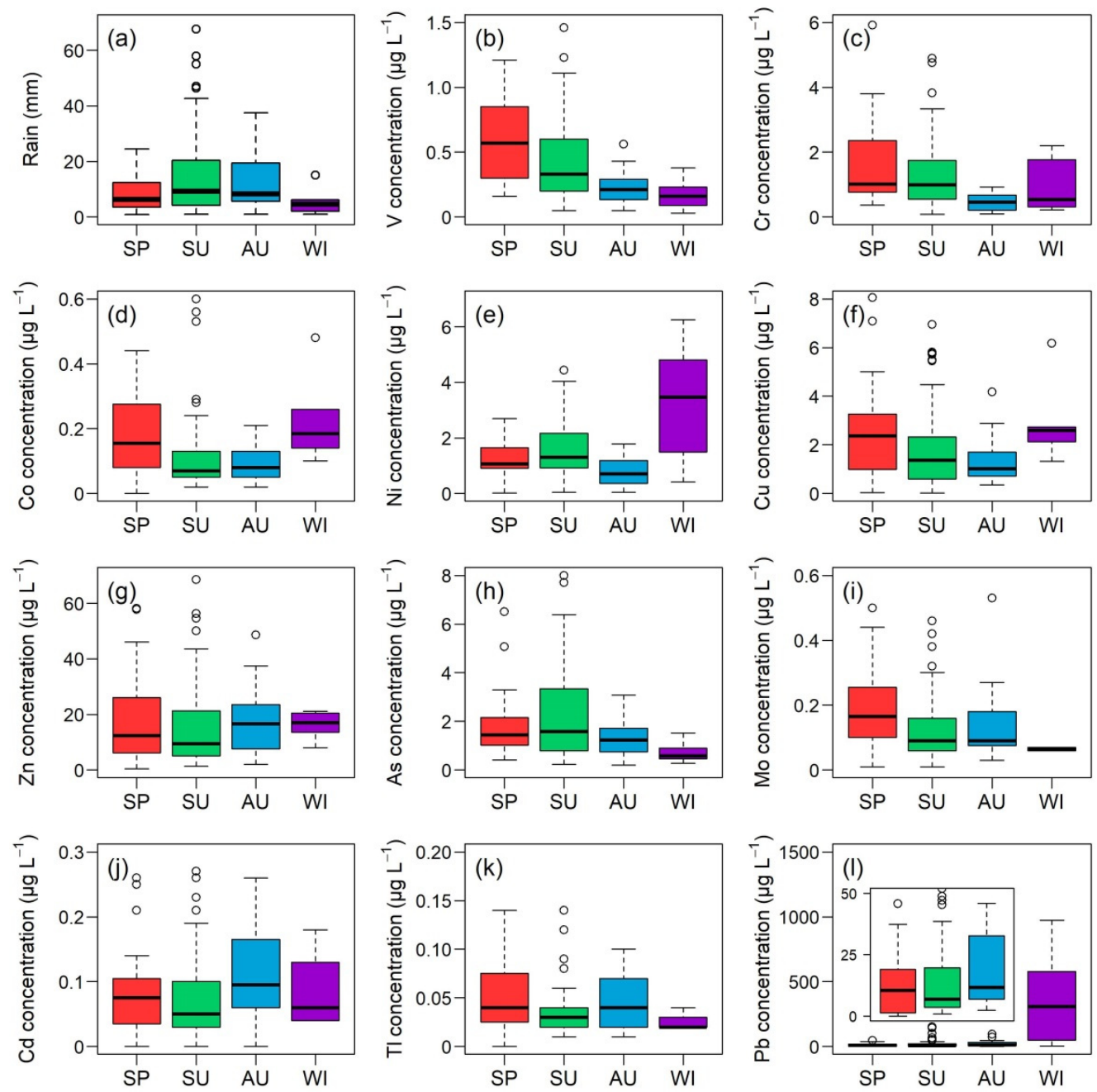

Figure 2. The seasonal variations of rainfall amount (a) and selected heavy metals and metalloids $(\mathrm{MMs},(\mathbf{b})=\mathrm{V},(\mathbf{c})=\mathrm{Cr}$, $(\mathbf{d})=\mathrm{Co},(\mathbf{e})=\mathrm{Ni},(\mathbf{f})=\mathrm{Cu},(\mathbf{g})=\mathrm{Zn},(\mathbf{h})=\mathrm{As},(\mathbf{i})=\mathrm{Mo},(\mathbf{j})=\mathrm{Cd},(\mathbf{k})=\mathrm{Tl},(\mathbf{l})=\mathrm{Pb})$ in bulk rain during 2017-2020 $(\mathrm{SP}=\mathrm{spring}$, $\mathrm{SU}=$ summer, $\mathrm{AU}=$ autumn, $\mathrm{WI}=$ winter). Box and whisker plot showing the maximum and minimum values (whiskers), the upper and lower quartiles (boxes) and the median (middle horizontal bolded line). Circles denote outliers beyond the whiskers. The data in autumn and winter $2016(n=2)$ was not included.

Table 1. The volume-weighted average and geometric mean concentrations $\left(\mu \mathrm{g} \mathrm{L}^{-1}\right)$ of $11 \mathrm{MMs}$ in bulk rain depositions observed during 2016-2020. The mean concentrations were also calculated according to air mass back-trajectory showing possible source directions.

\begin{tabular}{cccccccc}
\hline Heavy Metals & $\begin{array}{c}\text { 4-Year Average Concentrations } \\
\text { Volume-Weighted } \\
\text { Mean }\end{array}$ & $\begin{array}{c}\text { Geometric } \\
\text { Mean }\end{array}$ & Northwest & South & Southeast & Northeast & West \\
& 0.41 & 0.33 & 0.36 & 0.54 & 0.54 & 0.48 & 0.45 \\
$\mathrm{~V}$ & 1.38 & 0.89 & 0.71 & 2.06 & 1.93 & 1.30 & 1.36 \\
$\mathrm{Cr}$ & 0.17 & 0.10 & 0.08 & 0.19 & 0.16 & 0.16 & 0.23 \\
$\mathrm{Co}$ & 2.08 & 1.04 & 1.12 & 3.21 & 3.05 & 1.49 & 2.62 \\
$\mathrm{Ni}$ & 3.42 & 1.34 & 1.36 & 2.27 & 1.52 & 3.00 & 5.03 \\
$\mathrm{Cu}$ & 28.82 & 11.46 & 9.53 & 17.85 & 17.67 & 24.45 & 37.53 \\
$\mathrm{Zn}$ & 1.84 & 1.50 & 0.98 & 2.95 & 2.77 & 2.36 & 1.70 \\
$\mathrm{As}$ & 0.11 & 0.11 & 0.11 & 0.16 & 0.13 & 0.25 & 0.13 \\
$\mathrm{Mo}$ & 0.11 & 0.07 & 0.05 & 0.11 & 0.09 & 0.13 & 0.11 \\
$\mathrm{Cd}$ & 0.04 & 0.03 & 0.02 & 0.05 & 0.04 & 0.05 & 0.05 \\
$\mathrm{Tl}$ & 40.75 & 9.92 & 63.17 & 17.73 & 18.16 & 15.17 \\
$\mathrm{~Pb}$ & & & & & 98.29 \\
\hline
\end{tabular}




\subsection{Bulk Deposition Flux}

Table 2 summarized the annual mean flux of bulk deposition for selected MMs in this study, with results from other regions for reference. As shown, bulk deposition of $\mathrm{Pb}$ observed in this study showed the highest annual mean values $\left(12.02 \mathrm{mg} \mathrm{m}^{-2}\right.$ year $\left.{ }^{-1}\right)$, followed by $\mathrm{Zn}$ (6.18), As (0.65), Cu (0.56), Ni (0.53), Cr (0.41), V (0.16), Mo (0.04), Co (0.04), $\mathrm{Cd}(0.03)$ and $\mathrm{Tl}(0.01)$. These values were all lower than the total depositions observed at the mountainous site of Xinglong during 2007-2010, with a 4-year mean of 14.1, 40.7, $2.39,5.30,3.69,3.46,1.54,0.29,0.26,2.38$ and $0.13 \mathrm{mg} \mathrm{m}^{-2}$ year $^{-1}$, respectively [4]. The decreased atmospheric deposition of MMs in the region is expected, considering that a series of control measures were implemented in the past decade $[10,22]$. Even though, the presented bulk depositions of MMs were still higher than that observed in Europe. For example, the country-average deposition flux of $\mathrm{Pb}$ in Europe in 2018 was below $1 \mathrm{mg} \mathrm{m}^{-2}$ year $^{-1}$ [23], significantly lower than the value observed in this study.

Table 2. Summary of bulk deposition flux $\left(\mathrm{mg} \mathrm{m}^{-2}\right.$ year $\left.^{-1}\right)$ of $11 \mathrm{MMs}$ in this study and other measurement sites.

\begin{tabular}{|c|c|c|c|c|c|c|c|c|c|c|c|c|c|}
\hline Site & Period & $\mathbf{V}$ & $\mathrm{Cr}$ & Co & $\mathrm{Ni}$ & $\mathrm{Cu}$ & $\mathrm{Zn}$ & As & Mo & $\mathrm{Cd}$ & $\mathrm{Tl}$ & $\mathrm{Pb}$ & Reference \\
\hline $\begin{array}{c}\text { Rural Beijing, } \\
\text { China }\end{array}$ & 2016-2020 & 0.16 & 0.41 & 0.04 & 0.53 & 0.56 & 6.18 & 0.65 & 0.04 & 0.03 & 0.01 & 12.02 & this study \\
\hline Across China & 2013-2014 & - & $0.24-2.10$ & - & - & - & - & - & - & $0.03-0.95$ & - & $0.06-5.80$ & {$[24]$} \\
\hline South China & $2016-2018$ & - & 2.68 & - & 1.69 & 4.20 & 24.07 & 5.92 & - & 1.29 & - & - & [25] \\
\hline $\begin{array}{l}\text { Yangtze River } \\
\text { Delta, China }\end{array}$ & 2005-2018 & - & - & - & 23.49 & 11.07 & 29.66 & - & - & 0.26 & - & 12.27 & [26] \\
\hline $\begin{array}{c}\text { Chuncheon, } \\
\text { Korea }\end{array}$ & 2006-2009 & 0.10 & - & - & 0.37 & 1.21 & 6.93 & 0.26 & - & 0.05 & - & 1.06 & [27] \\
\hline $\begin{array}{l}\text { Bay of the Seine, } \\
\text { France }\end{array}$ & 2010-2011 & - & - & - & 0.32 & - & 2.85 & - & - & 0.01 & & 0.10 & [28] \\
\hline Caribbean, Cuba & $2014-2016$ & 3.91 & 1.02 & 0.10 & 1.28 & 3.21 & 21.90 & 0.44 & 0.11 & 0.03 & 0.005 & 2.34 & [29] \\
\hline $\begin{array}{c}\text { North } \\
\text { Kazakhstan }\end{array}$ & 2013-2018 & - & - & - & - & 3.80 & - & 0.11 & - & 0.06 & - & 0.57 & [30] \\
\hline
\end{tabular}

To gain broad insights into the pollution status of the above MMs that accumulated in bulk deposition, Table 2 also summarizes their flux observed at other rural and agricultural sites. While the observed bulk deposition of $\mathrm{V}, \mathrm{Cr}, \mathrm{Ni}$ and $\mathrm{Cu}$ were relatively low than other studies, the values of $\mathrm{Zn}$ and $\mathrm{Cd}$ in this study were in the middle range of the compilation. In contrast, the deposition of $\mathrm{Pb}$ and As was significantly higher than those in other sites within and outside of China (Table 2).

Figure 3 shows the temporal variations of bulk MMs depositions observed during 2017-2020. Summer always exhibited higher depositions than other seasons due to pattern of monsoon precipitation. For the annual deposition flux, $\mathrm{Zn}$, As and $\mathrm{Tl}$ decreased gradually from 2017 to 2020 (Figure 3). While the other MMs also tend to decrease from 2017 to 2020, the annual deposition flux of $\mathrm{V}, \mathrm{Cu}, \mathrm{Mo}, \mathrm{Cd}, \mathrm{Cr}, \mathrm{Co}$ and $\mathrm{Ni}$ in 2018 was comparable or significantly higher than other years. A decreasing trend was also found for $\mathrm{Pb}$ during the study period, with the exception of the aforementioned outliers in winter 2019. In general, the bulk deposition flux of MMs did not showed a consistent pattern between years with that of precipitation amount. This finding indicated that the annual variations of deposited MMs were not controlled by the precipitation amount. In other words, other factors determining the annual variations of MMs in bulk deposition, e.g., changes of emissions during these years [31], may account for the inter-annual differences in bulk depositions of MMs.

To judge how far the above results could be generalized, we plotted the annual variations of particulate matter concentrations from 2017-2020. As shown in Figure 4, the concentrations of $\mathrm{PM}_{2.5}$ showed a sharp decreasing trend, which is similar to the bulk deposition of $\mathrm{Zn}$ and As (Figure 3). In addition, the annual variations of $\mathrm{PM}_{10}$ concentrations were similar to the bulk deposition flux of $\mathrm{Cr}$ and $\mathrm{Ni}$, with relatively high values in 2018. These findings were self-consistent considering that the size distribution of aerosol $\mathrm{Zn}$ and $\mathrm{Cr}$, for examples, exist mainly in fine and coarse particulate forms [6], 
respectively. Thus, the different inter-annual patterns of MMs shown in Figure 3 are reasonable and agree well with their size distribution in particulate matter, showing a different pattern between fine and coarse particles (Figure 4).
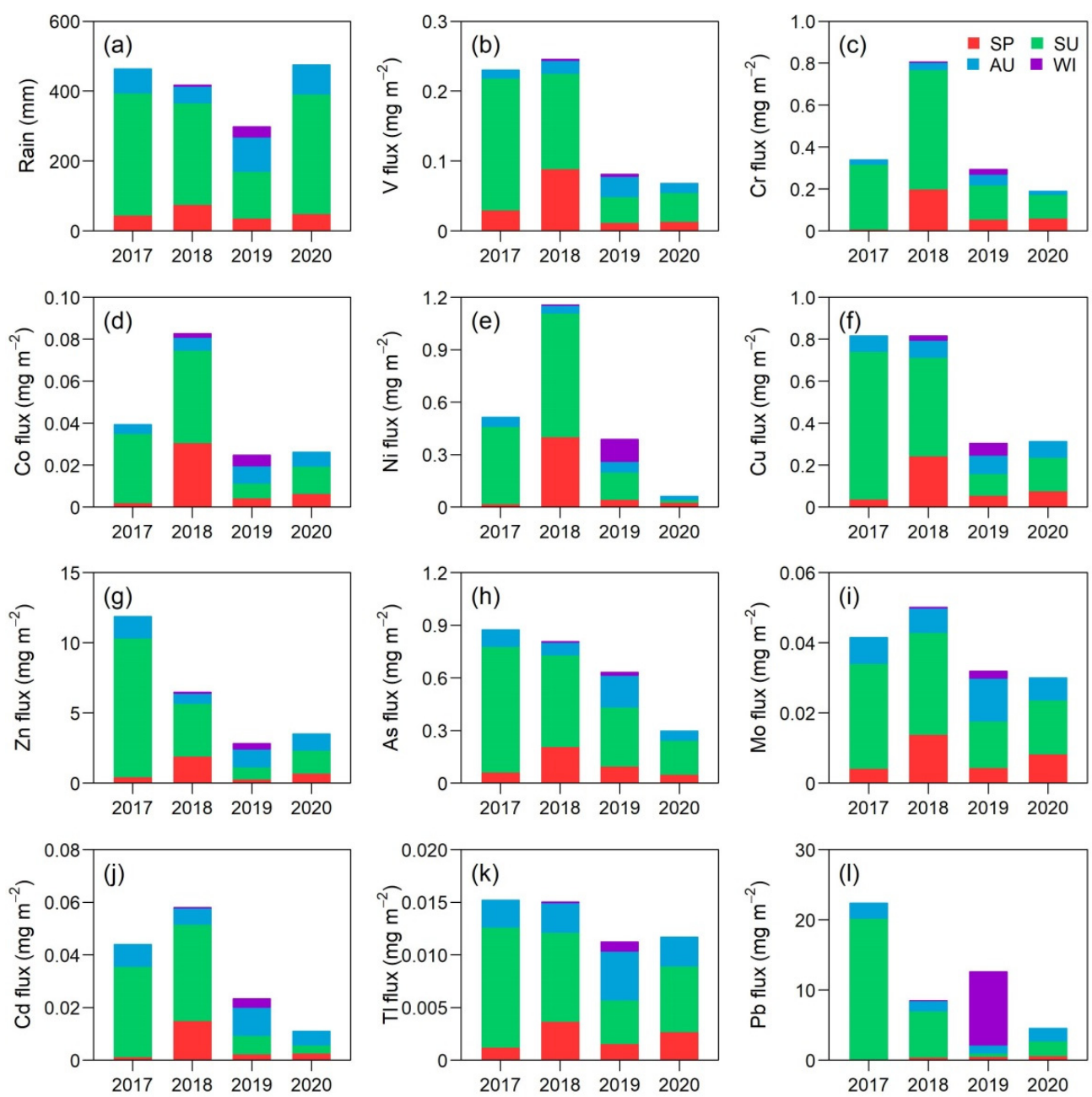

Figure 3. The annual variation of rainfall amount (a) and bulk deposition fluxes of $\mathrm{MMs}((\mathbf{b})=\mathrm{V}$, $(\mathbf{c})=\mathrm{Cr},(\mathbf{d})=\mathrm{Co},(\mathbf{e})=\mathrm{Ni},(\mathbf{f})=\mathrm{Cu},(\mathbf{g})=\mathrm{Zn},(\mathbf{h})=\mathrm{As},(\mathbf{i})=\mathrm{Mo},(\mathbf{j})=\mathrm{Cd},(\mathbf{k})=\mathrm{Tl},(\mathbf{l})=\mathrm{Pb})$ observed during 2017-2020 (SP = spring, $\mathrm{SU}=$ summer, $\mathrm{AU}=$ autumn, $\mathrm{WI}=$ winter). The data in autumn and winter $2016(n=2)$ was not included.
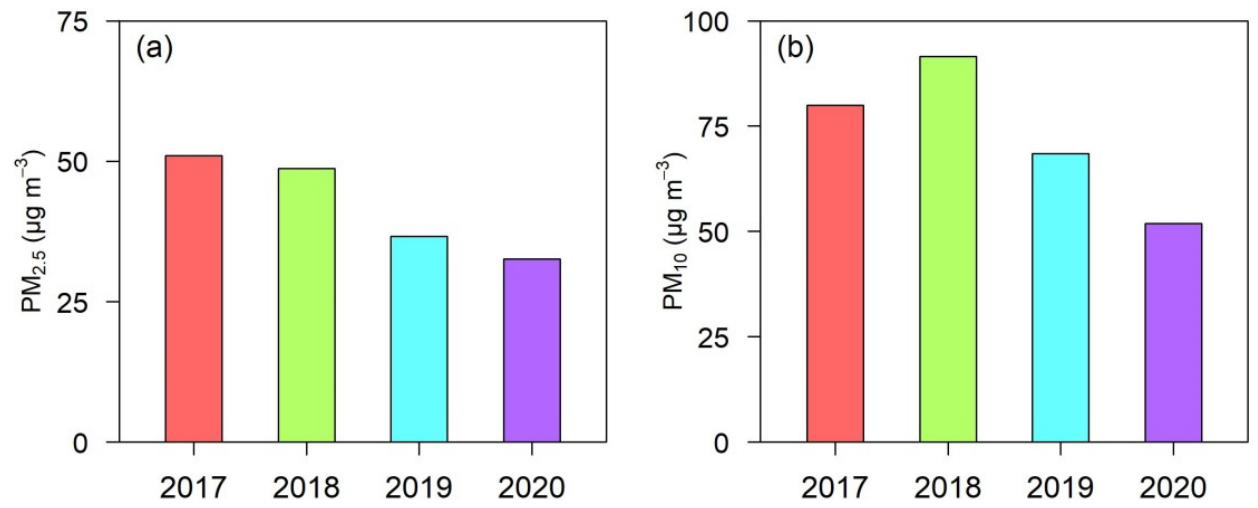

Figure 4. The annual mean concentrations of particulate matter with aerodynamic diameter less than $2.5 \mu \mathrm{m}(\mathbf{a})$ and $10 \mu \mathrm{m}(\mathbf{b})$ observed at a nearest monitoring station during 2017-2020 (data source: http://113.108.142.147:20035/emcpublish/, accessed on 31 December 2020). 
In addition, we further investigated the relative contribution of air mass transport paths between years, taken $\mathrm{Pb}$ for example. As shown in Figure 5, the potential source regions of $\mathrm{Pb}$ differ between years. In 2017, the hotspot sources referred to the surrounding NW and S areas, which is approximately $100 \mathrm{~km}$ from observation site. However, the hotspot source regions to the NW disappeared in other years. The contribution from NW areas may be the reason why the bulk deposition of $\mathrm{Pb}$ is higher in 2017. A unique feature also occurred in 2019, when the potential source regions were mainly identified to the far away NE. In 2018 and 2020, the PSCF analysis suggested a wide distributed sources covering the North China Plain. Considering the declining trend of particles in the region (Figure 4) and the fact that aerosol $\mathrm{Pb}$ existed entirely in fine particles [6], further reduction of bulk $\mathrm{Pb}$ deposition can be expected in future.

\subsection{Source Apportionment}

The PMF receptor model was applied to the data set for bulk depositions and five sources were identified for the entire sampling period of 2016-2020. Source contributions and plots of source profiles resolved from the observation site are presented in Figures 6 and 7, respectively. Five factors were identified: agricultural sources, dust, coal combustion, industrial and traffic emissions (Figure 6). These factors contributed $41.0 \%, 23.6 \%, 21.5 \%$, $9.3 \%$ and $4.6 \%$ of chemical materials in bulk deposition, respectively.
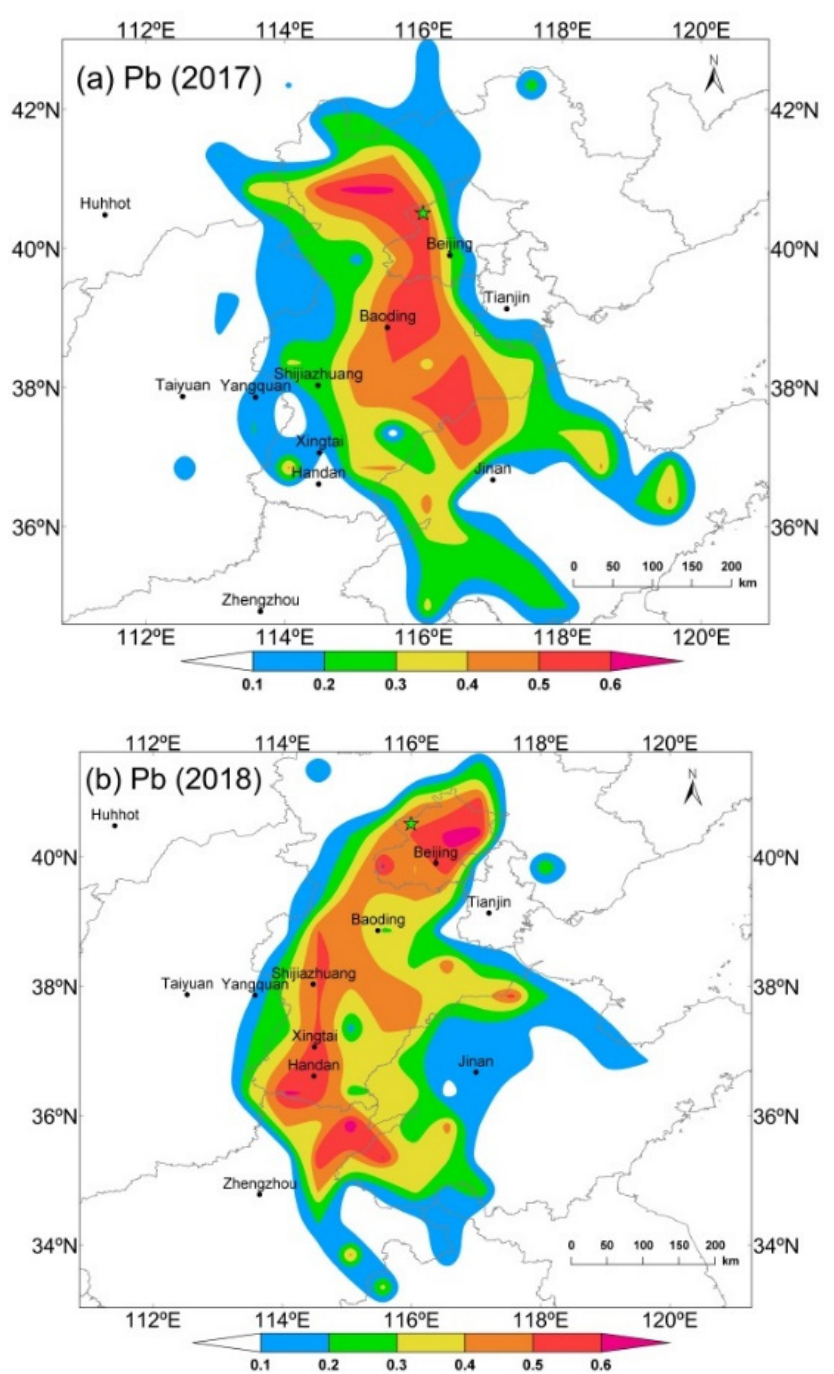

Figure 5. Cont. 

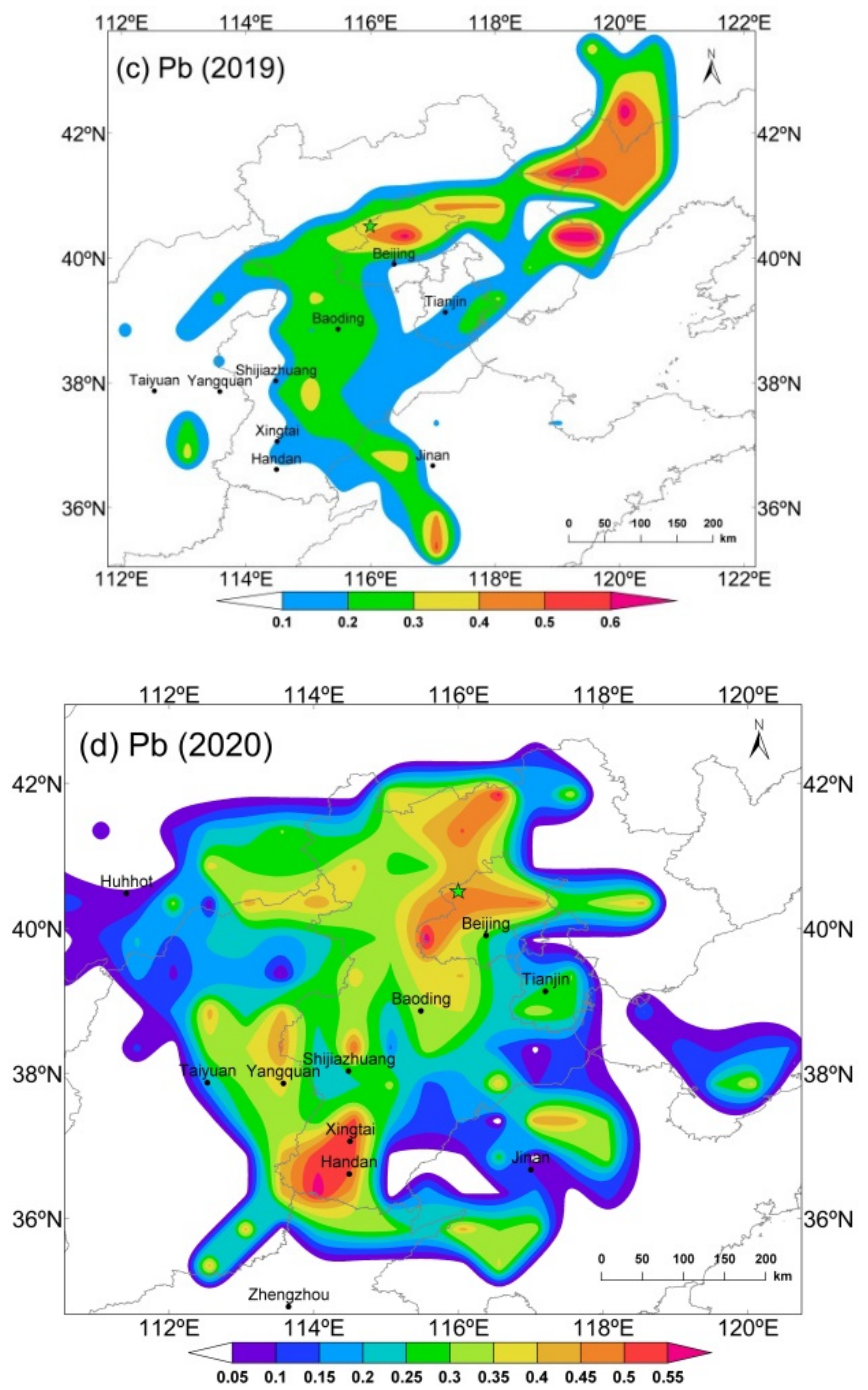

Figure 5. The potential source regions of atmospheric bulk $\mathrm{Pb}$ depositions according to potential source contribution function (PSCF) analysis in 2017 (a), 2018 (b), 2019 (c) and 2020 (d).

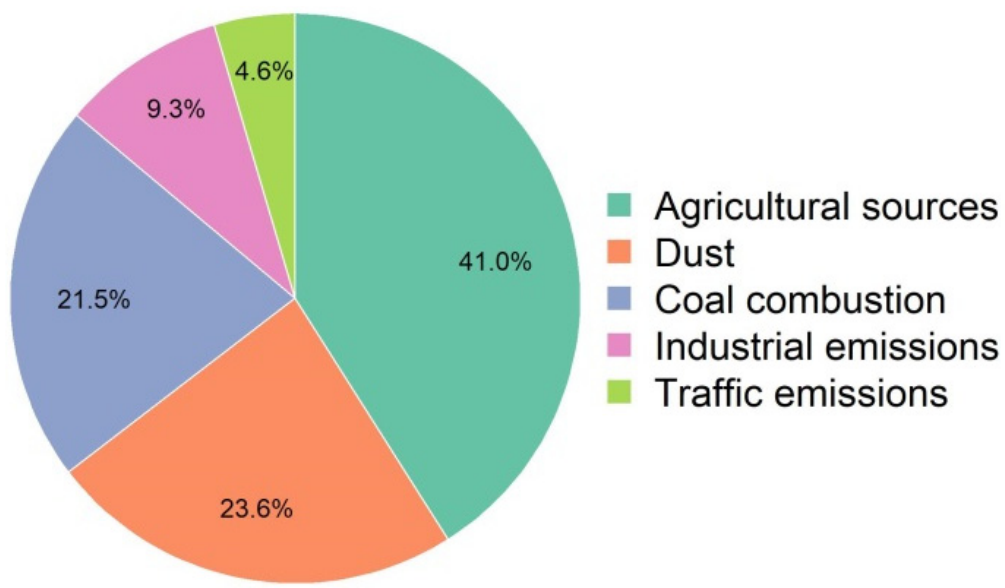

Figure 6. Source contributions resolved from atmospheric depositions at the observation site. 

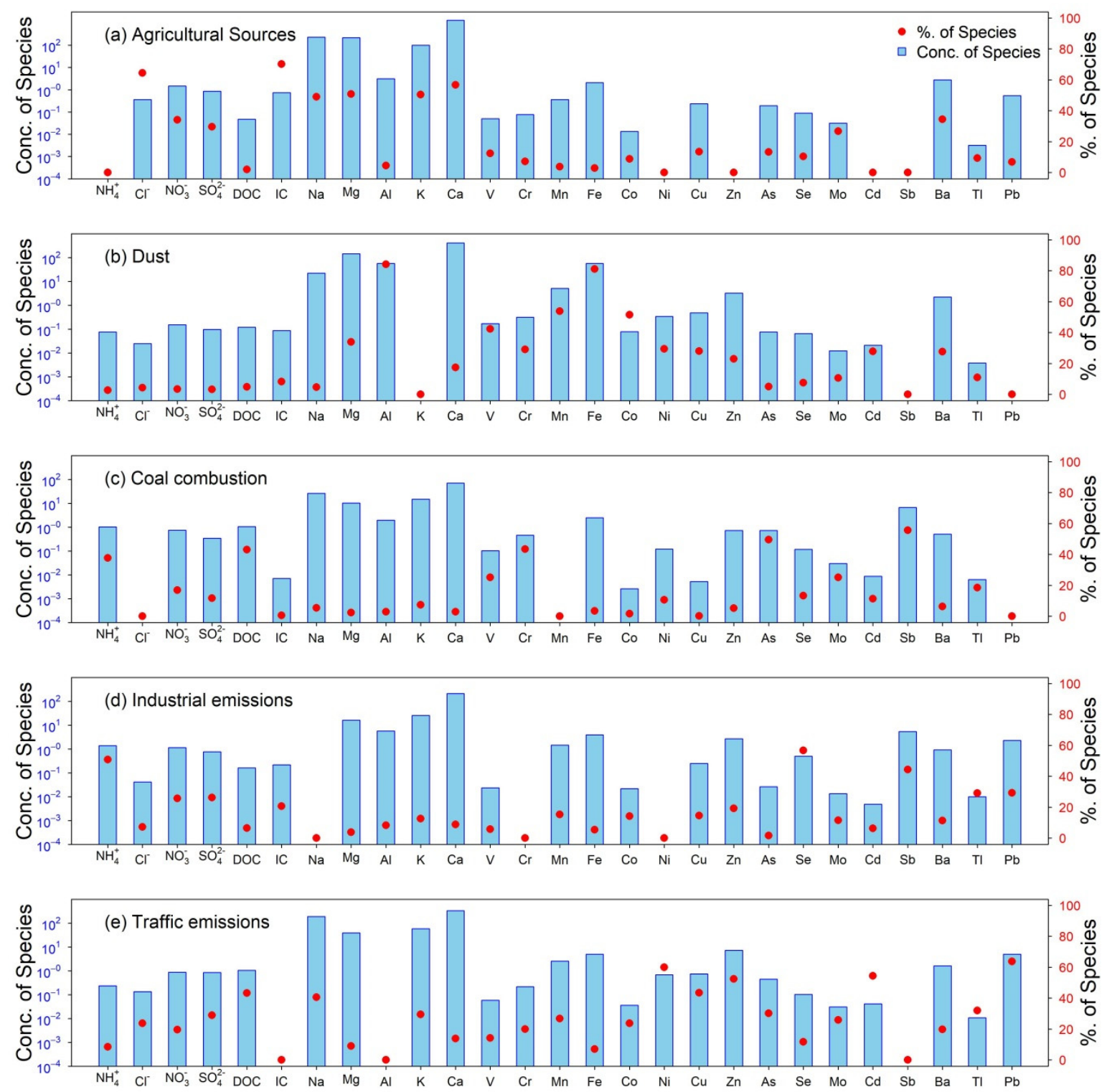

Figure 7. Source profiles resolved from atmospheric depositions at the observation site. Five sources were identified as agricultural sources (a), dust (b), coal combustion (c), industrial (d) and traffic emissions (e).

The first source was represented by high IC (70.3\%), $\mathrm{Cl}^{-}(56.7 \%), \mathrm{Ca}(56.8 \%), \mathrm{Mg}$ $(50.8 \%), \mathrm{K}(50.5 \%)$ and $\mathrm{Na}(49.0 \%)$ contents. This source was rich in mineral materials, e.g., calcium carbonate, which are related to bare soil emissions [32]. This source was also rich in $\mathrm{Cl}^{-}$and $\mathrm{K}$, which are excellent tracers of aerosols from biomass burning [33]. While $\mathrm{Cl}^{-}$and $\mathrm{K}$ exhibited the highest PSCF value in the area close to the Shijiazhuang city, the highest PSCF value of the other species were widely distributed in the region (Figure S2), which is mainly came from SW directions to the Mt. Taihang covering by farmlands. Thus, this factor may represent mixed sources from biomass burning and soil dust, which was assigned as agricultural source in this study.

The second source was relevant to dust. The main species were $\mathrm{Al}(84.2 \%), \mathrm{Fe}(81.1 \%)$, Mn (54.0\%), Co (51.5\%), V (42.4\%) and Mg (34.0\%), which are known to be crustal components and road dust [34-36]. Approximately one-quarter of bulk depositions came in this factor. As illustrated in the source region map (Figure S3), air masses containing dust components were widely distributed in the region with a focus along the Mt. Taihang.

The third source was coal combustion, as most Sb (55.6\%), As (49.6\%), Cr (43.4\%), DOC $(43.1 \%), \mathrm{NH}_{4}{ }^{+}(37.8 \%)$ and $\mathrm{Mo}(25.3 \%)$ came in this factor. These chemical components 
are important identification for coal combustion in the target region $[8,37,38]$. The PSCF analysis also suggested major sources in Beijing, Baoding and Shijiazhuang (Figure S4). The high PSCF value of Sb and As was mainly distributed in the area close to the Bohai Bay, central Hebei and western Shandong province.

The fourth component was industrial emissions, which was related to the high loading of Se (56.8\%), $\mathrm{NH}_{4}{ }^{+}(50.9 \%) \mathrm{Sb}(44.4 \%), \mathrm{Pb}(29.3 \%), \mathrm{SO}_{4}{ }^{2-}(26.3 \%)$ and $\mathrm{NO}_{3}{ }^{-}(25.7 \%)$. Given that these species are rich in smelters and metallurgical industries, this source may be relevant to the industrial plumes [39,40]. PSCF analysis supported this as the trajectories came from the SW (Figure S5), where numerous industrial factories were located. Considering the PSCF results, this factor was identified to represent the industrial emissions from Baoding, Shijiazhuang and Handan.

The fifth source, traffic emissions, was characterized by high $\mathrm{Pb}(63.7 \%), \mathrm{Ni}(59.9 \%)$, Cd (54.4\%), Zn (52.5\%), Cu (43.5\%) and DOC (43.4\%). These species are all related with vehicular emissions [41]. Our PSCF analysis referred to areas in southern Hebei and western Shandong province (Figure S6), along the major transport pathways in the North China Plain.

\section{Conclusions}

In this study we monitored atmospheric depositions and chemically characterized the daily bulk deposition samples at an agricultural site in rural Beijing. No consistent seasonality was found for the median concentrations of $11 \mathrm{MMs}$ in bulk deposition but lower values were observed in summer or autumn than winter or spring. In addition, elevated mean concentrations were found when air mass back trajectories were passing polluted western and southern regions. While the bulk deposition flux of MMs observed in this study declined substantially compared to the records ten years ago, the current deposition flux of $\mathrm{Pb}$, for example, is still higher than that reported in Europe. In addition, we found that the annual bulk deposition flux of MMs tended to decrease during 2017-2020, coinciding with the annual variations of particulate matter. We attributed this decline to the fluctuations of the emissions from their major sources rather than to precipitation controlling the deposition processes. To further reduce the airborne MMs in the North China Plain, future control measures should pay more attention to soil/dust, biomass burning, coal combustion and industrial emissions, all of which contributed to $90 \%$ of chemical components in atmospheric depositions.

This study represents a unique record on atmospheric deposition fluxes of MMs directly measured via bulk rain in rural Beijing and significantly expands the database for the North China Plain. The evidence provided here could be of help to establish efficient mitigation strategies for the prevention of the ecosystems from air pollution in China, with significant implications for other developing regions.

Supplementary Materials: The following are available online at https:/ / www.mdpi.com/2073-443 3/12/2/283/s1, Figure S1: Schematic image of the bulk deposition sampling. Figures S2-S6: The potential five source regions for atmospheric depositions according to PSCF analysis (Note that the chemical tracers were grouped by source types showing in Figure 7). Table S1: Sampling logsheet covering the period of November 2016 to November 2020.

Author Contributions: Conceptualization, Y.P.; methodology, Y.P.; software, J.L., J.H. and J.C.; formal analysis, J.C.; investigation, W.X. and S.T.; resources, L.Z.; data curation, J.C.; writing-original draft preparation, Y.P.; writing-review and editing, Y.P.; visualization, J.H.; supervision, Y.P.; project administration, Y.P.; funding acquisition, Y.P. and X.L. All authors have read and agreed to the published version of the manuscript.

Funding: This research was funded by the National Key Research and Development Program of China (Grants: 2016YFD0800302).

Institutional Review Board Statement: Not applicable.

Informed Consent Statement: Not applicable. 
Data Availability Statement: The data presented in this study are available on reasonable request from the corresponding author.

Acknowledgments: The authors are indebted to the site operators who collected the samples for this project. Special thanks go to graduated students in the lab for their valuable assistance in chemical analysis.

Conflicts of Interest: The authors declare no conflict of interest.

\section{References}

1. Qiao, Q.; Huang, B.; Zhang, C.; Piper, J.D.A.; Pan, Y.; Sun, Y. Assessment of heavy metal contamination of dustfall in northern China from integrated chemical and magnetic investigation. Atmos. Environ. 2013, 74, 182-193. [CrossRef]

2. Hovmand, M.F.; Kemp, K.; Kystol, J.; Johnsen, I.; Riis-Nielsen, T.; Pacyna, J.M. Atmospheric heavy metal deposition accumulated in rural forest soils of southern Scandinavia. Environ. Pollut. 2008, 155, 537-541. [CrossRef]

3. Nicholson, F.A.; Smith, S.R.; Alloway, B.J.; Carlton-Smith, C.; Chambers, B.J. An inventory of heavy metals inputs to agricultural soils in England and Wales. Sci. Total Environ. 2003, 311, 205-219. [CrossRef]

4. Pan, Y.P.; Wang, Y.S. Atmospheric wet and dry deposition of trace elements at 10 sites in Northern China. Atmos. Chem. Phys. 2015, 15, 951-972. [CrossRef]

5. Galloway, J.N.; Thornton, J.D.; Norton, S.A.; Volchok, H.L.; McLean, R.A.N. Trace metals in atmospheric deposition: A review and assessment. Atmos. Environ. 1982, 16, 1677-1700. [CrossRef]

6. Pan, Y.P.; Tian, S.L.; Li, X.R.; Sun, Y.; Li, Y.; Wentworth, G.R.; Wang, Y.S. Trace elements in particulate matter from metropolitan regions of Northern China: Sources, concentrations and size distributions. Sci. Total Environ. 2015, 537, 9-22. [CrossRef] [PubMed]

7. Mukherjee, A.B. Nickel: A review of occurrence, uses, emissions, and concentration in the environment in Finland. Environ. Rev. 1998, 6, 173-187. [CrossRef]

8. Tian, H.Z.; Zhu, C.Y.; Gao, J.J.; Cheng, K.; Hao, J.M.; Wang, K.; Hua, S.B.; Wang, Y.; Zhou, J.R. Quantitative assessment of atmospheric emissions of toxic heavy metals from anthropogenic sources in China: Historical trend, spatial distribution, uncertainties, and control policies. Atmos. Chem. Phys. 2015, 15, 10127-10147. [CrossRef]

9. Chen, R.; de Sherbinin, A.; Ye, C.; Shi, G. China's Soil Pollution: Farms on the Frontline. Science 2014, 344, 691. [CrossRef]

10. Geng, G.; Xiao, Q.; Zheng, Y.; Tong, D.; Zhang, Y.; Zhang, X.; Zhang, Q.; He, K.; Liu, Y. Impact of China's Air Pollution Prevention and Control Action Plan on $\mathrm{PM}_{2.5}$ chemical composition over eastern China. Sci. China Earth Sci. 2019, 62, 1872-1884. [CrossRef]

11. Dasch, J.M. Direct measurement of dry deposition to a polyethylene bucket and various surrogate surfaces. Environ. Sci. Technol. 1985, 19, 721-725. [CrossRef]

12. Shannigrahi, A.S.; Fukushima, T.; Ozaki, N. Comparison of different methods for measuring dry deposition fluxes of particulate matter and polycyclic aromatic hydrocarbons (PAHs) in the ambient air. Atmos. Environ. 2005, 39, 653-662. [CrossRef]

13. Wang, Y.; Yu, W.; Pan, Y.; Wu, D. Acid Neutralization of precipitation in Northern China. J. Air Waste Manag. 2012, 62, $204-211$. [CrossRef] [PubMed]

14. Pan, Y.; Wang, Y.; Xin, J.; Tang, G.; Song, T.; Wang, Y.; Li, X.; Wu, F. Study on dissolved organic carbon in precipitation in Northern China. Atmos. Environ. 2010, 44, 2350-2357. [CrossRef]

15. Tian, S.; Pan, Y.; Liu, Z.; Wen, T.; Wang, Y. Size-resolved aerosol chemical analysis of extreme haze pollution events during early 2013 in urban Beijing, China. J. Hazard. Mater. 2014, 279, 452-460. [CrossRef]

16. Karanasiou, A.A.; Siskos, P.A.; Eleftheriadis, K. Assessment of source apportionment by Positive Matrix Factorization analysis on fine and coarse urban aerosol size fractions. Atmos. Environ. 2009, 43, 3385-3395. [CrossRef]

17. Tian, S.L.; Pan, Y.P.; Wang, Y.S. Size-resolved source apportionment of particulate matter in urban Beijing during haze and non-haze episodes. Atmos. Chem. Phys. 2016, 16, 1-19. [CrossRef]

18. Wang, Y.Q.; Zhang, X.Y.; Draxler, R.R. TrajStat: GIS-based software that uses various trajectory statistical analysis methods to identify potential sources from long-term air pollution measurement data. Environ. Model. Softw. 2009, 24, 938-939. [CrossRef]

19. Ashbaugh, L.L.; Malm, W.C.; Sadeh, W.Z. A residence time probability analysis of sulfur concentrations at grand Canyon National Park. Atmos. Environ. 1985, 19, 1263-1270. [CrossRef]

20. Hopke, P.K.; Barrie, L.A.; Li, S.-M.; Cheng, M.-D.; Li, C.; Xie, Y. Possible sources and preferred pathways for biogenic and non-sea-salt sulfur for the high Arctic. J. Geophys. Res. Atmos. 1995, 100, 16595-16603. [CrossRef]

21. Berg, T.; Aas, W.; Pacyna, J.; Uggerud, H.T.; Vadset, M. Atmospheric trace metal concentrations at Norwegian background sites during 25 years and its relation to European emissions. Atmos. Environ. 2008, 42, 7494-7501. [CrossRef]

22. Xin, J.; Wang, Y.; Wang, L.; Tang, G.; Sun, Y.; Pan, Y.; Ji, D. Reductions of PM $_{2.5}$ in Beijing-Tianjin-Hebei urban agglomerations during the 2008 Olympic Games. Adv. Atmos. Sci. 2012, 29, 1330-1342. [CrossRef]

23. EMEP. Assessment of Transboundary Pollution by Toxic Substances: Heavy Metals and POPs. Part I. 2018. Available online: http:/ / en.msceast.org/reports/1_2020_datrep.pdf (accessed on 31 December 2020).

24. Zhu, J.; Wang, Q.; Yu, H.; Li, M.; He, N. Heavy metal deposition through rainfall in Chinese natural terrestrial ecosystems: Evidences from national-scale network monitoring. Chemosphere 2016, 164, 128-133. [CrossRef] 
25. Feng, W.L.; Guo, Z.H.; Peng, C.; Xiao, X.Y.; Shi, L.; Zeng, P.; Ran, H.Z.; Xue, Q.H. Atmospheric bulk deposition of heavy metal(loid)s in central south China: Fluxes, influencing factors and implication for paddy soils. J. Hazard. Mater. 2019, 371, 634-642. [CrossRef]

26. Ma, Y.; Tang, Y.; Xu, H.; Zhang, X.; Liu, H.; Wang, S.; Zhang, W. Bulk/wet deposition of trace metals to rural, industrial, and urban areas in the Yangtze River Delta, China. Ecotoxicol. Environ. Saf. 2019, 169, 185-191. [CrossRef]

27. Kim, J.-E.; Han, Y.-J.; Kim, P.-R.; Holsen, T.M. Factors influencing atmospheric wet deposition of trace elements in rural Korea. Atmos. Res. 2012, 116, 185-194. [CrossRef]

28. Connan, O.; Maro, D.; Hebert, D.; Roupsard, P.; Goujon, R.; Letellier, B.; Le Cavelier, S. Wet and dry deposition of particles associated metals (Cd, Pb, Zn, Ni, Hg) in a rural wetland site, Marais Vernier, France. Atmos. Environ. 2013, 67, 394-403. [CrossRef]

29. Morera-Gomez, Y.; Santamaria, J.M.; Elustondo, D.; Lasheras, E.; Alonso-Hernandez, C.M. Determination and source apportionment of major and trace elements in atmospheric bulk deposition in a Caribbean rural area. Atmos. Environ. 2019, 202, 93-104. [CrossRef]

30. Cherednichenko, V.S.; Cherednichenko, A.V.; Cherednichenko, A.V.; Zheksenbaeva, A.K.; Madibekov, A.S. Heavy metal deposition through precipitation in Kazakhstan. Heliyon 2021, 7, e05844. [CrossRef]

31. Mijic, Z.; Stojic, A.; Perisic, M.; Rajsic, S.; Tasic, M.; Radenkovic, M.; Joksic, J. Seasonal variability and source apportionment of metals in the atmospheric deposition in Belgrade. Atmos. Environ. 2010, 44, 3630-3637. [CrossRef]

32. Oduber, F.; Calvo, A.I.; Castro, A.; Blanco-Alegre, C.; Alves, C.; Calzolai, G.; Nava, S.; Lucarelli, F.; Nunes, T.; Barata, J.; et al. Characterization of aerosol sources in León (Spain) using Positive Matrix Factorization and weather types. Sci. Total Environ. 2021, 754, 142045. [CrossRef]

33. Du, H.; Kong, L.; Cheng, T.; Chen, J.; Du, J.; Li, L.; Xia, X.; Leng, C.; Huang, G. Insights into summertime haze pollution events over Shanghai based on online water-soluble ionic composition of aerosols. Atmos. Environ. 2011, 45, 5131-5137. [CrossRef]

34. Desboeufs, K.; Bon Nguyen, E.; Chevaillier, S.; Triquet, S.; Dulac, F. Fluxes and sources of nutrients and trace metals atmospheric deposition in the northwestern Mediterranean. Atmos. Chem. Phys. 2018, 18, 1-27. [CrossRef]

35. Titos, G.; Lyamani, H.; Pandolfi, M.; Alastuey, A.; Alados-Arboledas, L. Identification of fine $\left(\mathrm{PM}_{1}\right)$ and coarse $\left(\mathrm{PM}_{10-1}\right)$ sources of particulate matter in an urban environment. Atmos. Environ. 2014, 89, 593-602. [CrossRef]

36. Vecchi, R.; Chiari, M.; D’Alessandro, A.; Fermo, P.; Lucarelli, F.; Mazzei, F.; Nava, S.; Piazzalunga, A.; Prati, P.; Silvani, F.; et al. A mass closure and PMF source apportionment study on the sub-micron sized aerosol fraction at urban sites in Italy. Atmos. Environ. 2008, 42, 2240-2253. [CrossRef]

37. Tian, H.Z.; Wang, Y.; Xue, Z.G.; Cheng, K.; Qu, Y.P.; Chai, F.H.; Hao, J.M. Trend and characteristics of atmospheric emissions of $\mathrm{Hg}$, As, and Se from coal combustion in China, 1980-2007. Atmos. Chem. Phys. 2010, 10, 11905-11919. [CrossRef]

38. Kang, J.; Choi, M.-S.; Yi, H.-I.; Song, Y.-H.; Lee, D.; Cho, J.-H. A five-year observation of atmospheric metals on Ulleung Island in the East/Japan Sea: Temporal variability and source identification. Atmos. Environ. 2011, 45, 4252-4262. [CrossRef]

39. Dall'Osto, M.; Querol, X.; Amato, F.; Karanasiou, A.; Lucarelli, F.; Nava, S.; Calzolai, G.; Chiari, M. Hourly elemental concentrations in $\mathrm{PM}_{2.5}$ aerosols sampled simultaneously at urban background and road site during SAPUSS-diurnal variations and PMF receptor modelling. Atmos. Chem. Phys. 2013, 13, 4375-4392. [CrossRef]

40. Karnae, S.; John, K. Source apportionment of fine particulate matter measured in an industrialized coastal urban area of South Texas. Atmos. Environ. 2011, 45, 3769-3776. [CrossRef]

41. Begum, B.A.; Kim, E.; Biswas, S.K.; Hopke, P.K. Investigation of sources of atmospheric aerosol at urban and semi-urban areas in Bangladesh. Atmos. Environ. 2004, 38, 3025-3038. [CrossRef] 